\title{
Analgesic and anti-inflammatory properties of aqueous extract of Deverra scoparia Coss and Dur obtained from Tamanrasset, Algeria
}

\author{
Lilya Harchaoui*, Djamila Chabane, Saida Ouafi \\ Research Laboratory on Arid Zones (LRZA) Faculty of Biological Sciences, University of Sciences and Technology Houari \\ Boumediene (USTHB), Algiers, Algeria
}

*For correspondence: Email: lilya.h@live.fr; Tel: 213(0)21467539; Fax: 213(0)21639141

Sent for review: 22 December 2017

Revised accepted: 17 July 2018

\begin{abstract}
Purpose: To determine the toxicity, anti-inflammatory and analgesic properties of Deverra scoparia Coss. \& Dur. and the phenolic compounds involved

Methods: The aqueous extract of Deverra scoparia Coss. \& Dur. was intra-gastrically administered at increasing doses $(2,4,8,12$ and $16 \mathrm{~g} / \mathrm{kg})$ to mice of both sexes in order to study its acute toxicity. Analgesic activity was evaluated in mice and rats using acetic acid-induced writhing and formalin tests at doses of 250, 500 and $1000 \mathrm{mg} / \mathrm{kg}$. Anti-inflammatory activity was assessed by carrageenan-induced paw oedema method, while the bioactive compounds in the extract were identified by high performance liquid chromatography (HPLC) analysis.

Results: The extract $(1000 \mathrm{mg} / \mathrm{kg})$ produced significant inhibition in acetic acid-induced writhing $(71.18$ $\%)$ and formalin ( $83.58 \%$ ) tests; and $73.52 \%$ reduction of carrageenan-induced rat paw oedema test ( $p$ $<0.001)$. HPLC analysis revealed the presence of two phenolic acids, viz, salicylic acid (21.81 $\mathrm{mg} / \mathrm{g}$ dry weight) and rosmarinic acid (28.44 $\mathrm{mg} / \mathrm{g}$ dry weight); and apigenin, a flavonoid aglycone $(5.70 \mathrm{mg} / \mathrm{g}$ dry weight).

Conclusion: These results indicate that the extract of Deverra scoparia Coss. \& Dur. is non-toxic even at a dose of $16 \mathrm{~g} / \mathrm{kg}$. The extract possesses significant analgesic and anti-inflammatory potential which may be due to the presence of phenolic compounds (apigenin, salicylic acid and rosmarinic acid).
\end{abstract}

Keywords: Deverra scoparia Coss. \& Dur., Acute toxicity, Anti-inflammatory, Analgesic, HPLC, Phenolic compounds

\begin{abstract}
This is an Open Access article that uses a funding model which does not charge readers or their institutions for access and distributed under the terms of the Creative Commons Attribution License (http://creativecommons.org/licenses/by/4.0) and the Budapest Open Access Initiative (http://www.budapestopenaccessinitiative.org/read), which permit unrestricted use, distribution, and reproduction in any medium, provided the original work is properly credited.
\end{abstract}

Tropical Journal of Pharmaceutical Research is indexed by Science Citation Index (SciSearch), Scopus, International Pharmaceutical Abstract, Chemical Abstracts, Embase, Index Copernicus, EBSCO, African Index Medicus, JournalSeek, Journal Citation Reports/Science Edition, Directory of Open Access Journals (DOAJ), African Journal Online, Bioline International, Open-J-Gate and Pharmacy Abstracts

\section{INTRODUCTION}

For centuries, medicinal plants have been widely used for the treatment of various ailments [1]. Indeed, about $80 \%$ of the people from developing countries depend on traditional remedies for their primary health care [2]. The use of alternative medicines derived from natural sources has also spread to the industrialized nations. Indeed, a variety of herbal plants has been extensively used for the extraction of pure compounds used in the development of new drugs [3]. Pain is a disabling discomfort associated with many medical conditions. One of 
the most important therapeutic priorities in handling pain involves pain control [4]. Synthetic drugs like non-steroidal anti-inflammatory drugs (NSAIDs), opioids and corticosteroids are the major clinically-used drugs for treating and reducing pain. However, their long term usage may induce toxic effects such as ulcers of gastrointestines, nausea, hemorrhage, and kidney disorders [5]. In this regard, there is a need to search for medicinal plant-derived bioactive compounds with little or no side effects, for use as alternative analgesic and antiinflammatory agents [6].

Deverra scoparia Coss. \& Dur., a medicinal plant belonging to the Apiaceae family, is an endemic species of North African origin. Based on ethnobotanical evidence reported in the literature [7-9], the aerial parts of Deverra scoparia Coss. \& Dur. have very important pharmacological properties $[7,8]$. This plant is used by the Algerian local population (Tergui) to treat several infectious diseases, digestive disorders and to calm abdominal pain [7]. However, extensive review of extant literature has revealed that no pharmacological studies have been so far been conducted on the acute toxicity, antiinflammatory activity and the analgesic potential of Deverra scoparia Coss. \& Dur. The present study was carried out to determine the antiinflammatory and analgesic properties of Deverra scoparia Coss. \& Dur. and the identity of the active compounds responsible for these activities.

\section{EXPERIMENTAL}

\section{Plant material}

Deverra scoparia Coss. \& Dur. was collected in March, 2016 from Hoggar area located in Tamanrasset region (South of Algeria), and was identified by a taxonomist, Pr. Saida Ouafi, of Department of Biological Sciences of University of Sciences and Technology Houari Boumediene. A voucher specimen (number 38) was deposited at the herbarium of the National Institute of Agronomy, Algeria (INA). The aerial parts of the plant were shade-dried at room temperature $\left(24 \pm 2{ }^{\circ} \mathrm{C}\right)$ and preserved in paper bags, in order to avoid fungal contamination. The plant material $(1 \mathrm{Kg})$ was chopped into small pieces with a knife and then ground to a fine powder in an electric blender.

\section{Preparation of aqueous extract}

An aqueous extract of Deverra scoparia Coss. \& Dur. was prepared using infusion method. The powdered plant material was macerated, with continuous stirring in boiling distilled water for a few minutes, and the resultant infusion was filtered through Whatman no. 1 filter paper.

\section{Experimental animals}

Healthy male and female Wistar albino rats (mean weight $=200 \pm 20 \mathrm{~g}$ ) and healthy male and female albino mice, Mus musculus (mean weight $=20 \pm 5 \mathrm{~g}$ ) were obtained from Animal Laboratory of Biotic Unit (Saidal, Algeria). The animals were fed pellet diet from the National Office of Animal Feed (Bejaia-Algeria). The pellet feed and drinking water were provided ad libitum. The animals were also kept and maintained under standard laboratory conditions at a temperature of $24 \pm 2^{\circ} \mathrm{C}, 12 \mathrm{~h}$ light/dark cycle, and relative humidity in the range of 50 to $55 \%$. All experimental procedures were approved by the University Animal Experimentation Ethics Committee (approval ref no. 162/2011/8), and followed the recommendation of the care and use guide for laboratory animals [10].

\section{Acute oral toxicity test}

The acute oral toxicity test of the aqueous infusion extract of Deverra scoparia Coss. \& Dur. was determined as per OECD-423 guidelines, but with slight modifications [11]. Sixty albino mice were divided into six equal groups $(n=10 ; 5$ males and 5 females), one of which was used as a control. The mice were fasted for $12 \mathrm{~h}$ prior to the experiment but were allowed free access to drinking water. Different doses of the aqueous extract $(2,4,8,12$ and $16 \mathrm{~g} / \mathrm{kg})$ were administered, each in a volume of $0.5 \mathrm{~mL}$, while mice in the control group received $0.5 \mathrm{~mL}$ of sterile saline water $(0.9 \% \mathrm{NaCl})$. Close observations of behavioral changes in the mice was conducted up to $4 \mathrm{~h}$ following extract administration, and once every day until the fourteenth day. The behavioral changes of interest were salivation, diarrhea, tremors, ataxia, hyperactivity, lethargy, convulsions, sleep and coma. At the end of the observation period, the animals were anaesthetized, sacrificed and autopsied. The heart, lung, kidney and liver samples were excised and examined for any lesions in the treated groups, relative to the control group.

\section{Determination of analgesic activity}

\section{Acetic acid-induced writhing test}

This study was performed using the abdominal writhing method described by Koster et al [12] and modified by Vogel [13]. Thirty albino mice of both sexes were randomly divided into five 
groups each containing six mice. The aqueous infusion extract of Deverra scoparia Coss. \& Dur. was administered separately by gastric gavage to three of the mice groups at doses of 250,500 and $1000 \mathrm{mg} / \mathrm{kg}$ per body weight. The negative and positive control groups received sterile saline water $(0.9 \% \mathrm{NaCl})$ and Aspirin $(500 \mathrm{mg} / \mathrm{kg})$, respectively.

Thirty minutes after oral administration of the aqueous infusion extract and the drug, $0.6 \%$ acetic acid $(1 \mathrm{~mL} / \mathrm{kg}$ ) was given intraperitoneally to induce pain which was manifested in abdominal constrictions (writhes). After $5 \mathrm{~min}$, each group of mice was monitored for the number of writhes within $15 \mathrm{~min}$. The percentage of inhibition by plant extract and aspirin against acetic acid-induced abdominal writhing was used to evaluate the degree of analgesia $(A)$ and was calculated for each group using $\mathrm{Eq} 1$.

$A(\%)=\left[\left(1-W_{e} / W_{t}\right)\right] 100$

where $W_{e}$ represents the mean value of writhes in treated groups and $W_{t}$ represents the mean value of writhes in control groups.

\section{Formalin test}

Formalin test was carried out using the methods of Hunskaar et al [14] and Miranda et al [15]. Rats of both sexes were divided into five groups (six rats per group); three groups were orally treated (separately) with the aqueous infusion extract at doses of 250, 500 and $1000 \mathrm{mg} / \mathrm{kg}$ per body weight, Aspirin (500 mg/kg) and sterile saline $(0.9 \% \mathrm{NaCl})$ were administered orally to the other two groups which served as positive and negative controls, respectively. Thirty minutes after treatment, $50 \mu \mathrm{L}$ of $2.5 \%$ formalin was injected subcutaneously into the dorsal surface of the right hind paw. The time spent in licking the injected paw was recorded by visual observation in the early phase $(0-5 \mathrm{~min})$ and late phase (15 - $30 \mathrm{~min})$. The inhibition of licking (L) for both phases was calculated as in Eq 2 .

$L(\%)=\left[\left(1-D_{t}\right) / D_{0}\right] 100$

where, $D_{t}$ is the mean value of licking time in the treated groups, and $D_{0}$ is the mean value of licking time in the control groups.

\section{Determination of anti-inflammatory activity}

The anti-inflammatory activity of the aqueous infusion extracted of the aerial parts of Deverra scoparia Coss. \& Dur. was determined using the procedure previously described by Levy [16]. Albino mice were divided into five groups (six animals per group). Group I, (negative control) mice were treated with $0.9 \%$ sterile saline, whereas mice in group II (positive control) were treated with diclofenac sodium $(500 \mathrm{mg} / \mathrm{kg})$. The remaining groups (III, IV and V) received the aqueous infusion extract at three different concentrations (250, 500 and $1000 \mathrm{mg} / \mathrm{kg}$ per body weight, respectively). One hour after the oral administration of all treatments, oedema was induced by injecting carrageenan suspension $(0.05 \mathrm{~mL}, 1 \% \mathrm{w} / \mathrm{v})$ into the sub-plantar tissues of the right hind paw of all mice. After $3 \mathrm{~h}$ the animals were anesthetized with diethyl ether and sacrificed. The two posterior legs were excised at the tarsal joint and then weighed in an analytical balance.

For each mouse, the percentage oedema was calculated after recording the increase in the weight of the right posterior leg which received the carrageenan suspension, and the weight of the healthy left posterior leg. The percentage of oedema (O \%) was calculated by determining the mean weight of both legs for each group, according to Eq 3.

$\mathrm{O}(\%)=\{[\mathrm{M}(\mathrm{RLW})-\mathrm{M}(\mathrm{LLW})] / \mathrm{M}(\mathrm{LLW})\} 100$

where, $\mathrm{O}(\%)$ is the oedema percentage, $M(R L W)$ is the mean weight of the right leg per group, and $M(L L W)$ is the mean weight of the left leg per group.

The anti-inflammatory activity was calculated as the percentage inhibition of oedema between the test and control groups following the Eq 4

$1 \%=[(\%$ co $-\%$ to $) / \%$ co $] 100$

where, I (\%) is the inhibition percentage, \%c o is the $\%$ of the control oedema and $\%$ to is the $\%$ of the test oedema.

\section{HPLC analysis}

HPLC analysis was carried out for the identification and quantification of phenolic compounds in the extract using Agilent series 1100 chromatography system coupled with UV Detector and bars of Diodes Surveyor, equipped with quaternary rapid separation pump. Separation was performed on Hypersil BDS-C18 column $(250 \times 4.6 \mathrm{~mm}, 5 \mu \mathrm{m})$. Analysis was carried out injecting $20 \mu \mathrm{L}$, while the mobile phase consisted of two solvents: acetic acid ( $0.2 \%$ of acetic acid in water) and acetonitrile in a linear gradient for $30 \mathrm{~min}$ at a flow rate of 1.5 $\mathrm{mL} / \mathrm{min}$. The mobile phase started with $95 \%$ of acetic acid, and ended with $100 \%$ of acetonitrile. 


\section{Statistical analysis}

Data are expressed as mean \pm standard error of mean (SEM). Statistical analysis was performed using one-way analysis of variance (ANOVA), followed by Tukey's test. Values of $p<0.001$ and $p<0.05$ were considered statistically significant.

\section{RESULTS}

\section{Acute toxicity}

The acute toxicity test was carried out in order to determine the toxicity of the aerial parts of Deverra scoparia Coss. \& Dur. during the 14 days observation period, no behavioural changes, such as convulsion, hyperactivity, irritability diarrhea or mortalities were observed. The weights of the mice were not affected at any of the administered doses and all the vital organs (kidney, liver, lung and heart) were healthy and normal following necropsy. There were also no signs of cysts, swelling or hamorrhage.

\section{Analgesic activity}

\section{Acetic acid-induced writhing}

Table 1: Effects of aqueous infusion extract of Deverra scoparia Coss. \& Dur. and aspirin on acetic acid-induced writhing test in mice

\begin{tabular}{lcc}
\hline $\begin{array}{l}\text { Treatment/dose } \\
\text { (mg/kg) }\end{array}$ & $\begin{array}{c}\text { Number of } \\
\text { writhings } \\
\text { responses }\end{array}$ & $\begin{array}{c}\text { Inhibition } \\
(\%)\end{array}$ \\
\hline $\begin{array}{l}\text { Control (normal } \\
\text { saline) }\end{array}$ & $59 \pm 4.00$ & - \\
$\begin{array}{l}\text { Aspirin (500) } \\
\begin{array}{l}\text { Aqueous extract } \\
(250)\end{array}\end{array}$ & $31 \pm 1.89^{*}$ & 47.45 \\
$\begin{array}{l}\text { Aqueous extract } \\
(500)\end{array}$ & $29 \pm 1.41^{* \#}$ & 50.84 \\
$\begin{array}{l}\text { Aqueous extract } \\
(1000)\end{array}$ & $17 \pm 1.61^{*} \#$ & 61.01 \\
\hline $\begin{array}{l}\text { Data represent mean } \pm \text { SEM }(n=6) ; \quad p<0.001 \\
\text { compared with control group; }{ }^{*} p<0.05 \text { compared with } \\
\text { aspirin (One-way ANOVA followed by Tukey's multiple } \\
\text { comparison test) }\end{array}$ &
\end{tabular}

The results showed that administration of the different doses of the aqueous infusion extract of Deverra scoparia Coss. \& Dur. significantly $(p<$ 0.001 ) reduced abdominal writhing in mice, when compared with the negative control group. All doses of the aqueous infusion extract showed strong significant analgesic action in the tested animals, by inhibiting the acetic acid-induced writhing dose-dependently, causing 50.84, 61.01 and $71.18 \%$ of inhibitions at 250, 500 and 1000 $\mathrm{mg} / \mathrm{kg}$, respectively. In contrast, aspirin (500 $\mathrm{mg} / \mathrm{kg}$ ) produced only $47.45 \%$ writhing inhibition effect (Table 1).

\section{Formalin test results}

The evaluation of the analgesic activity was conducted using the formalin test. The results on Table 2 show that the extract produced significant and dose-dependent percentage inhibition of the number of writhes at the early and late phases, when compared with the control group $(p<0.001)$. Maximum percentage inhibition was obtained at a dose of $1000 \mathrm{mg} / \mathrm{Kg}$ ( $71.42 \%$ in early phase), and $(83.58 \%$ in the late phase).

\section{Anti-inflammatory activity}

Oral administration of the aqueous infusion extract of aerial parts of Deverra scoparia Coss. \& Dur. to mice with carrageenan-induced hind paw oedema produced significant $(p<0.001)$ anti-inflammatory activity at all doses tested (Error! Reference source not found.). There was a gradual decrease in oedema paw volume from $15.66 \%$ at $250 \mathrm{mg} / \mathrm{kg}$ down to $8.68 \%$ at a dose of $1000 \mathrm{mg} / \mathrm{kg}$, indicating that the effect of the extract was dose-dependent. Similarly, a significant increase $(p<0.001)$ in percentage inhibition of carrageenan-associated oedema was produced at $250(52.22 \%), 500(66.13 \%)$ and $1000(73.52 \%) \mathrm{mg} / \mathrm{kg}$ while the reference drug diclofenac sodium exhibited $47.95 \%$ inhibition.

Table 2: Analgesic effect of aqueous infusion extract of Deverra scoparia Coss. \& Dur. and aspirin on paw licking time in early and late phases of formalin test in rats

\begin{tabular}{lcccc}
\hline \multirow{2}{*}{ Treatment/dose (mg/kg) } & \multicolumn{2}{c}{ Early phase } & \multicolumn{2}{c}{ Late phase } \\
\cline { 2 - 5 } & Licking time (s) & Inhibition (\%) & Licking time (s) & $\begin{array}{c}\text { Inhibition } \\
\text { (\%) }\end{array}$ \\
\hline Control (Normal saline) & $119 \pm 7.21$ & - & $195 \pm 7.74$ & - \\
Aspirin (500) & $49 \pm 4.69^{*}$ & 58.88 & $60 \pm 1.88^{*}$ & 69.23 \\
Aqueous extract (250) & $42 \pm 1.78^{*}$ & 64.70 & $50 \pm 1.78^{*}$ & 74.35 \\
Aqueous extract (500) & $40 \pm 1.41^{*}$ & 66.38 & $41 \pm 1.09^{*}$ & 78.97 \\
Aqueous extract (1000) & $34 \pm 1.67^{*}$ & 71.42 & $32 \pm 1.41^{*}$ & 83.58 \\
\hline
\end{tabular}

Data represent mean \pm SEM $(n=6) ; p<0.001$ compared with control group; ${ }^{\#} p<0.05$ compared with aspirin (One-way ANOVA followed by Tukey's multiple comparison test) 
Table 3: Anti-inflammatory effect of the aerial parts of Deverra scoparia Coss. \& Dur. and diclofenac sodium on carrageenan-induced hind paw oedema in mice ( $R L W$ right leg weight; $L L W$ left leg weight)

\begin{tabular}{|c|c|c|c|c|}
\hline \multirow{2}{*}{ Treatment/dose (mg/kg) } & \multicolumn{2}{|c|}{ Mean weight (M) } & \multirow{2}{*}{$\begin{array}{c}\text { Oedema } \\
(\%)\end{array}$} & \multirow[b]{2}{*}{ Inhibition (\%) } \\
\hline & $R L W(g)$ & $L L W(g)$ & & \\
\hline Control (normal saline) & $0.1134 \pm 0.009$ & $0.0854 \pm 0.004$ & 32.78 & - \\
\hline Diclofenac sodium (500) & $0.1113 \pm 0.004^{\pi}$ & $0.0955 \pm 0.003^{\pi}$ & 17.06 & 47.95 \\
\hline Aqueous extract (250) & $0.1159 \pm 0.003^{*}$ & $0.1002 \pm 0.005^{\star} \#$ & 15.66 & 52.22 \\
\hline Aqueous extract (500) & $0.1141 \pm 0.005^{*}$ & $0.1027 \pm 0.004^{* \#}$ & 11.10 & 66.13 \\
\hline Aqueous extract (1000) & $0.1151 \pm 0.006^{*}$ & $0.1059 \pm 0.004^{*}$ & 8.68 & 73.52 \\
\hline
\end{tabular}

Data represent mean \pm SEM $(n=6) ; p<0.001$ compared with control group; ${ }^{*} p<0.05$ compared with aspirin (One-way ANOVA followed by Tukey's multiple comparison test)

\section{HPLC chromatograms}

Phenolic compounds in the aqueous infusion extract of aerial parts of Deverra scoparia Coss. \& Dur. were identified and quantified by HPLC. The profile (Figure 1) was detected at $365 \mathrm{~nm}$, the wavelength used for the detection of several flavonoid compounds.

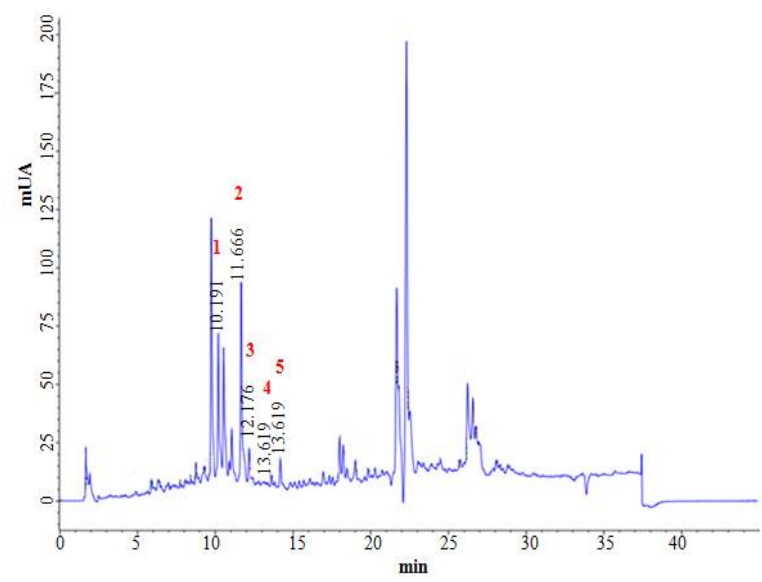

Figure 1: HPLC profile of phenolic compounds from the aqueous infusion extract of the aerial parts of Deverra scoparia Coss. \& Dur. measured at $365 \mathrm{~nm}$

Table 4: Retention times and relative contents of phenolic compounds present in the aqueous infusion extract of Deverra scoparia Coss. \& Dur.

\begin{tabular}{cclc}
\hline Peak & $\begin{array}{c}\text { Retention } \\
\text { time (min) }\end{array}$ & $\begin{array}{c}\text { Phenolic } \\
\text { compound }\end{array}$ & $\begin{array}{c}\text { Relative } \\
\text { content } \\
\text { (mg/g dry } \\
\text { weight) }\end{array}$ \\
\hline 1 & 10.191 & Salicylic acid & 21.81 \\
2 & 11.666 & Rosmarinic & 28.44 \\
3 & 12.176 & acid & Luteolin \\
4 & 13.619 & Kaempferol & 6.96 \\
5 & 14.186 & Apigenin & 3.63 \\
\hline
\end{tabular}

The HPLC chromatogram revealed the presence of several compounds, five were identified by comparison with their retention times and UV absorbance of purified external standards. Three flavonoids (luteolin, apigenin and kaempferol), and two phenolic acids (salicylic acid and rosmarinic acid) were identified. Table 4 shows the retention times and relative content of the bioactive phenolic compounds present in the aqueous infusion extract of the aerial parts of Deverra scoparia Coss. \& Dur.

\section{DISCUSSION}

Many people world-wide have depended, and still depend on the natural healing capacity of medicinal plants for their health care needs. Since some plants might have potential toxic effects, toxicity assays are an important aspect of the research on the medicinal plants [17]. In this study, the acute toxicity of the aerial parts of Deverra scoparia Coss. \& Dur. was investigated. There were no toxicities or mortalities at doses ranging from $2000 \mathrm{mg} / \mathrm{kg}$ up to $16000 \mathrm{mg} / \mathrm{kg}$. Thus, based on the toxicity scale of Hodge and Sterner, the aerial parts of Deverra scoparia Coss. \& Dur. can be considered as non-toxic [18].

In addition, the present work was conducted to assess the analgesic and anti-inflammatory activities of aerial parts of Deverra scoparia Coss. \& Dur. Acetic acid-induced writhing test is conducted in order to study any drug's peripheral analgesic effects. The analgesic effect of the aqueous infusion extract following intraperitoneal injection of acetic acid is due to the release of several chemical mediators such as histamines and prostaglandins, particularly prostaglandins E2 [19]. Prostaglandins activate the peripheral chemo-sensitive nociceptive receptors, leading to the induction of abdominal constrictions which are accompanied by extension of the forelimbs and elongation of the body [20]. The aqueous infusion extract of Deverra scoparia Coss. \& Dur. at dose of $250 \mathrm{mg} / \mathrm{kg}, 500 \mathrm{mg} / \mathrm{kg}$ and 1000 $\mathrm{mg} / \mathrm{kg}$ significantly reduced the number of writhes, surpassing the effect of the reference drug aspirin which was used at a dose of 500 $\mathrm{mg} / \mathrm{kg}$. 
In addition, the aqueous infusion extract at different doses $(250,500$ and $1000 \mathrm{mg} / \mathrm{kg}$ ) showed significant reduction in the time spent in licking and biting (in both phases), when compared with the reference drug. These results are manifestations of the inhibitory effects of the plant extract on inflammation induced by injection of formalin into the intraplantar region of animal's hind paw. Two phases are involved in the model of nociception, with the neurogenic phase's nociceptive activity is mediated by the transmission of nociceptive impulses, while the anti-inflammatory phase occurs through the activation of central neurons at the spinal cord level [21] involving inflammatory mediators like bradykinin, histamine, serotonin and prostaglandin [1].

The present study shows that the aqueous infusion extract of Deverra scoparia Coss. \& Dur. significantly reduced carrageenan-induced paw oedema, when compared to the reference drug, diclofenac sodium $(500 \mathrm{mg} / \mathrm{Kg})$. This inhibition of inflammation may be due to the blockage of the synthesis of some mediators such as histamines and prostaglandins by the plant extract [21]. In order to reveal the nature of the phytochemical compounds that could be responsible for these biological activities, HPLC analysis was performed. The results showed the presence of three potential bioactive molecules, two of which are phenolic acids, salicylic acid $(21.81 \mathrm{mg} / \mathrm{g}$ dry weight) and rosmarinic acid (28.44 mg/g dry weight), and one flavonoid aglycone, (apigenin $5.70 \mathrm{mg} / \mathrm{g}$ dry weight). These compounds may account for the observed anti-inflammatory and analgesic activities of the extract. Many studies have demonstrated that salicylic acid exerts potential analgesic and anti-inflammatory effect by blocking the enzymes responsible for the production of prostaglandins and thromboxanes $[22,23]$. Rosmarinic acid reduces inflammation by inhibiting prostaglandins biosynthesis [24], while apigenin inhibits inflammation by suppressing the expression of cycolooxygenase2 (COX-2), a pro-inflammation enzyme [25].

\section{CONCLUSION}

The aqueous extract of Deverra scoparia Coss. \& Dur. possesses analgesic and antiinflammatory properties. These pharmacological properties could be due to the presence of bioactive phenolic compounds such as salicylic and rosmarinic acids as well as apigenin.

\section{DECLARATIONS}

\section{Acknowledgement}

This project was funded by The General Directorate of Scientific Research and Technological Development in Algeria and supported by the University of Sciences and Technology Houari Boumediene Algiers, Algeria.

\section{Conflict of Interest}

No conflict of interest associated with this work.

\section{Contribution of Authors}

The authors declare that this work was done by the authors named in this article and all liabilities pertaining to claims relating to the content of this article will be borne by them.

\section{REFERENCES}

1. Ridtitid W, Sae-Wong C, Reanmongkol W, Wongnawa $M$. Antinociceptive activity of the methanolic extract of Kaempferia galanga Linn. in experimental animals. J Ethnopharmacol 2008; 118: 225-230.

2. Verma S, Singh SP. Current and future status of herbal medicine. Vet World 2008; 1: 347-350.

3. Sahreen S, Khan MR, Khan RA, Alkreathy HM. Cardioprotective role of leaves extracts of Carissa opaca against CC/4 induced toxicity in rats. BMC Res Notes 2014; 7(1): 224-232.

4. Rang HP, Dale MM, Ritter JM, Moore PK. Pharmacology. Fifth Edition, Churchill Livingstone, Edinburgh; 2003. $797 p$.

5. Griffin M, Marie R. Epidemiology of nonsteroidal antiinflammatory drug-associated gastrointestinal injury. Am J Med 1998; 104(3): 23-29.

6. Ezeja M, Omeh Y, Ezeigbo I, Ekechukwu A. Evaluation of the analgesic activity of the methanolic stem bark extract of Dialium guineense (wild). Ann Med Health Sci Res 2011; 1(1): 55-62.

7. Attia S, Grissa KL, Lognay G, Heuskin S, Mailleux AC, Hance T. Chemical composition and acaricidal properties of Deverra Scoparia essential oil (Araliales: Apiaceae) and blends of its major constituents against Tetranychus urticae (Acari: Tetranychidae). J Econ Entomol 2011; 104(4): 1220-1228.

8. Adida $H$, Frioui $E$, Djaziri $R$, Mezouar D. In vitro antibacterial activity of Pituranthos scoparius from Algeria. Int J Biol Chem Sci 2014; 8(5): 2095-2108.

9. Chermat $S$, Gharzouli R. Ethnobotanical study of medicinal flora in the North East of Algeria - an empirical knowledge in Djebel Zdimm (Setif). J Mater Sci Eng A 2015; 5 (1-2):50-59.

10. $h t t p: / / w w w . m f . g o v . d z / a r t i c l e \_p d f / u p /-$ 504bd7dd74ba8cab5c9516396a0d3ddf.pdf.

11. OECD. Guidelines number 423 for testing chemicals. Acute Oral Toxicity - Acute Toxic Class Method. 2001. Available

from: 
https://ntp.niehs.nih.gov/iccvam/suppdocs/feddocs/oecd/ oecd_g/423.

12. Koster R, Anderson M, Debeer EJ. Acetic acid for analgesic screening. Fed Proc 1959; 18: 412-415.

13. Vogel GH. Drug discovery and evaluation, Pharmacological assay. 2nd ed. New York: SpringerVerlag- Berlin Heidlberg; 2002. 1385p.

14. Hunskaar S, Fasmer OB, Hole K. Formalin test in mice, a useful technique for evaluating mild analgesics. $J$ Neurosci Methods 1985; 4: 69-76.

15. Miranda FG, Vilar JC, Alves IA, Cavalcanti SC, Antoniolli AR. Antinociceptive and antioedematogenic properties and acute toxicity of Tabebuia avellanedae Lor. ex Griseb. inner bark aqueous extract. BMC Pharmacol 2001; 1(6): 1-9.

16. Levy L. Carrageenan paw oedema in the mouse. Life Sci.1969; 8: 601-606.

17. Mustaffa F, Indurkar J, Ismail S, Mordi MN, Ramanathan S, Mansor SM. Analgesic activity, toxicity study and phytochemical screening of standardized Cinnomomum iners leaves methanolic extract. Pharmacognosy Res 2010; 2(2): 76-81

18. Hodge HC, Sterner J. Determination of substances acute toxicity by DL50.Am Ind Hyg Assoc 1943; 10: 93-96.

19. Derardt $R$, Jongney S, Delvalcee F, Falhout M. Release of prostaglandins $E$ and $F$ in an algogenic reaction and its inhibition. Eur J Pharmacol 1980; 61(1): 17-24.
20. Collier HO, Dinneen LC, Johnson, CA, Schneider $C$. The abdominal constriction response and its suppression by analgesic drug in the mouse. $\mathrm{Br} J$ Pharmacol Chemother 1968; 32(2): 295-310.

21. Dubuisson D, Dennis SG. The formalin test: $A$ quantitative study of the analgesic effects of morphine, meperidine, and brain stem stimulation in rats and cats. Pain 1977; 4:161-174.

22. Morris CJ. Carrageenin-induced paw oedema in the rat and mouse. Methods Mol Biol 2003; 225: 115-121.

23. Kim HP, Son K.H, Chang HW, Kang SS. Antiinflammatory plant flavonoids and cellular action mechanisms. J Pharmacol Sci 2004; 96: 229-245.

24. Rocha J, Eduardo-Figueira M, Barateiro A, Fernandes A, Brites $D$, Bronze $R$, Duarte $C M$, Serra $A T$, Pinto $R$, Freitas $M$, Fernandes $E$, Silva-Lima $B$, Mota-Filipe $H$, Sepodes B. Basic Clin Pharmacol Toxicol 2015; 116(5): 398-413.

25. Lee JH, Zhou HY, Cho SY, Kim YS, Lee YS, Jeong CS, Anti-inflammatory mechanisms of apigenin: inhibition of cyclooxygenase-2 expression, adhesion of monocytes to human umbilical vein endothelial cells, and expression of cellular adhesion molecules. Arch Pharm Res 2007; 30(10): 18-27. 